\title{
Chiemite - a high PT carbon impactite from shock coalification/carbonization of impact target vegetation
}

\author{
K. Ernstson"1, T. G. Shumilova ${ }^{2}$ \\ 1University of Würzburg, Würzburg, Germany; kernstson@ernstson.de \\ 2IG FRC Komi SC UB RAS, Syktyvkar, Russia; shumilova@geo.komisc.ru
}

\section{Introduction}

Unusual carbonaceous matter in the form of mostly centimeter-sized lumps and cobbles has been sampled in the southeast Bavarian Alpine Foreland, in the Czech Republic near Pardubice and in the Saarland region near the French border (Fig. 1). It is a highly porous blackish material with a glassy luster on freshly crushed surfaces (Fig. 2). The material is unknown from any industrial or other anthropogenic processes and thus appears to have a natural origin. Here we report on results of a detailed analysis of this strange matter pointing to a process of formation in proposed meteorite impact events. From its first discovery in the Bavarian Chiemgau impact crater strewn field [1] the name chiemite gained currency, and in particular these finds have already been addressed earlier (references in [1]) before a more general occurrence in impact sites became obvious $[2,3]$.

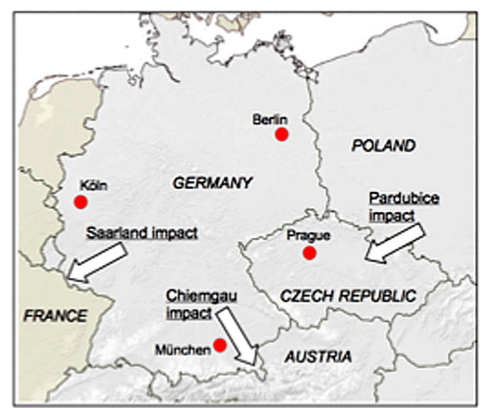

Fig. 1. Location map for the three chiemite sources in the Chiemgau, Saarland and Czech impact strewn fields

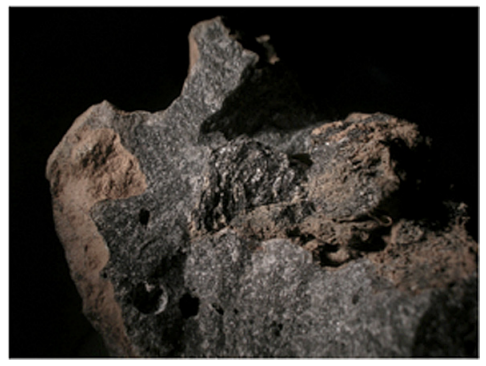

Fig. 2. Freshly broken chiemite sample. Photo width $6 \mathrm{~cm}$

\section{Material}

Typical chiemite samples from the field are shown in Fig. 3 as pure chiemite matter, where the pseudomorphosis after wood sticks out, and in compound with rock and organic matter. Under the SEM the typical strongly porous texture is evident. Physical properties are a low density mostly $<1 \mathrm{~g} / \mathrm{cm}^{3}$, a significant electrical conductivity and in some cases a moderate magnetic susceptibility and remnant magnetization.

\section{Methods (with a focus} on the Chiemgau impact chiemite):

Optical and atomic force microscopy, X-ray fluorescence spectroscopy, scanning and transmission electron microscopy (SEM, TEM), high-resolution Raman spectroscopy, X-ray diffraction and differential thermal analysis, as well as $\delta^{13} \mathrm{C}$ and ${ }^{14} \mathrm{C}$ radiocarbon isotopic data analysis.

\section{Results}

The most significant observations described in [4] are tabulated in short as follows.
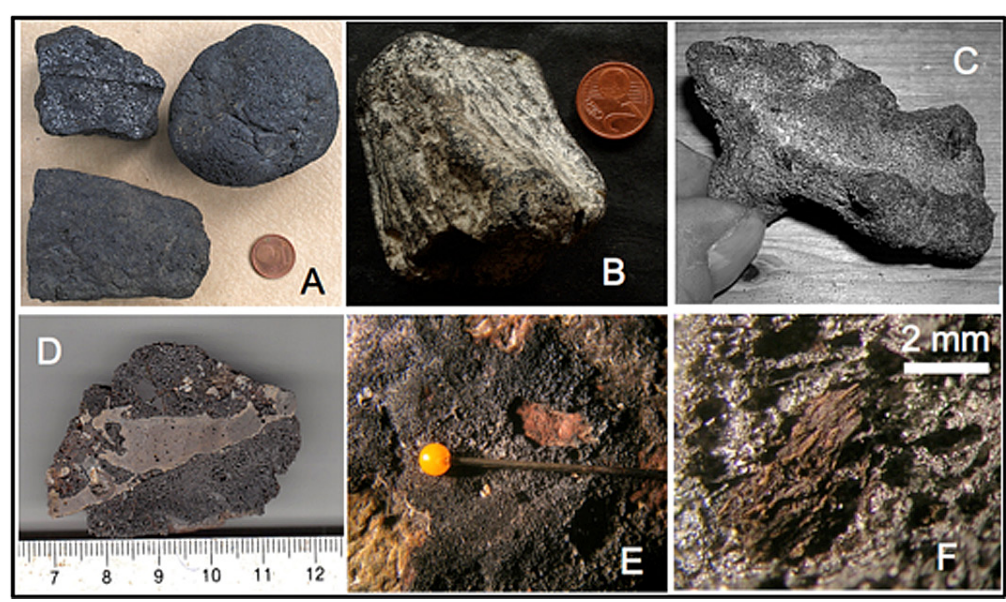

Fig. 3. Chiemite samples from the field. A: various shapes. B, C: chiemite fragments pseudomorphic after pieces of branches. D: chiemite breccia-like intermeshed with a limestone cobble. E: chiemite crust on a sandstone cobble. F: relatively fresh wood particle embedded in chiemite [4] 

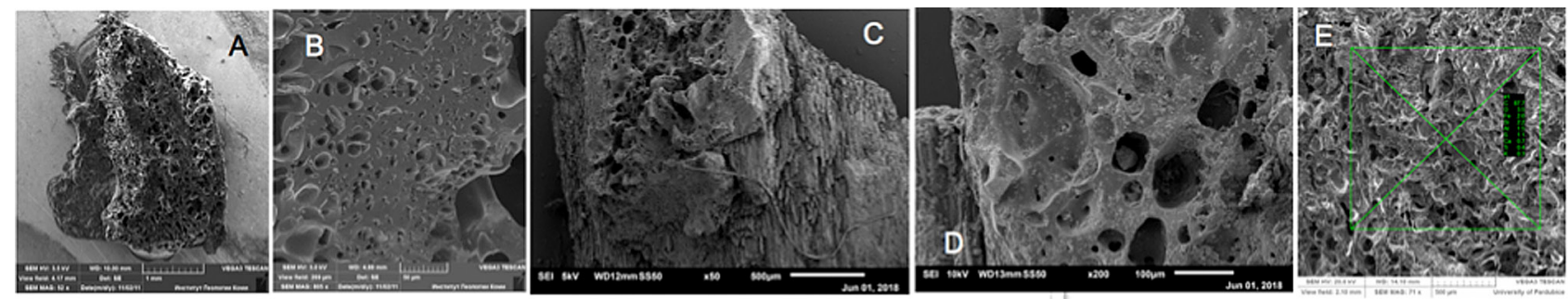

Fig. 4. Chiemite under the SEM. Chiemgau impact (A, B) [3], Saarland impact (C, D), Czech impact (E). Fossilized wooden structure in $\mathrm{C}$

XRF: about $90 \%$ carbon, remaining $\mathrm{Si}, \mathrm{Al}$ and $\mathrm{Fe}$, subordinately S; traces of other elements.

SEM, microprobe: almost pure glass-like carbon matrix contains finely dispersed micrometer- and submicrometer-sized inclusions with a complex composition not known mineralogically.

XRD, XR synchrotron diffraction: Evidence of nanocrystalline diamond and graphite.

TEM: Glass-like carbon structural features. Crystalline carbyne and diamond matter with different order level.

TEM and Raman: Polycrystalline fine grained aggregates to polynanocrystalline diamond aggregates and amorphous diamond-like carbon exists. - $\alpha$-carbyne and $\beta$-carbyne but not any graphite were observed.

Raman spectroscopy: Submicrometer-sized optically transparent substances are carbyne-like carbon or diamond-like carbon.

Carbon isotopes: Carbon $\delta^{13} \mathrm{C}_{\mathrm{PDB}}$ data show values between -22.6 and $-24.6 \%$ near to data of C3 plants.

Radiocarbon data for two chiemite samples are void of ${ }^{14} \mathrm{C}$ corresponding to an age of $>48,000$ years BP not compatible with the chiemite find situation.

\section{Discussion and conclusions}

The fully amorphous chiemite matrix contains diamond, amorphous diamond-like carbon and monocrystalline carbyne inclusions. The strongly porous texture requires an intense gas phase during formation. - Carbyne formation needed very high PT conditions of about 4-6 GPa and 2,500$4,000 \mathrm{~K}$. Probable carbon glass was formed at temperatures as high as $3,800-4,000 \mathrm{~K}$. - Organic matter was involved in the formation process. The lack of ${ }^{14} \mathrm{C}$ requires an age $>48,000$ years (less probable) or isotope separation. - Chiemite does not correspond to any known natural earth material. An industrial formation and an occurrence from e.g. wildfires can reasonably be excluded. -
The chiemite components show similarities to after-coal meteorite impacts [5]. - We propose the chiemite was formed by meteorite impact shock having affected vegetation like wood and peat in the impact target area, hence establishing a new kind of impactite that originated from immediate shock transformation of organic matter to highrank carbon. - The impactite nature is underlined by the occurrence of chiemite samples in three established or proposed young impact strewn fields (Fig. 1). The finds closely resembling each other up to the enigmatic absence of ${ }^{14} \mathrm{C}$ despite their evident young ages, and a so far unknown isotope separation in the impact process has to be assumed. - In all three impact cases there is much evidence of big airbursts, which initiated extreme-temperature gas jets impinging on the ground. - The surviving of fresh organic matter in the impactite under these extreme conditions is important for astrobiological aspects. - The prediction $[5,6]$ of more impact diamonds from organic matter than hitherto assumed is likewise underlined.

The authors thank Isaenko S. I., Ulyashev V. V., Makeev B. A., Rappenglück M. A., Veligzhanin A. A. for help in the analytical studies and discussion.

\section{References}

1. Rappenglück, M. A., Rappenglück, B. \& Ernstson. K. Cosmic collision in prehistory. - The Chiemgau Impact: research in a Bavarian meteorite crater strewn field // Zeitschrift für Anomalistik. 2017. V 17. P. 235260.

2. Ernstson, K., Müller, W., Neumair, A. The proposed Nalbach (Saarland, Germany) impact site: is it a companion to the Chiemgau (Southeast Bavaria, Germany) impact strewn field? // 2013. 76th Annual Meteoritical Society Meeting, 5058.

3. Molnár, M., Ventura, K., Švanda, P., Štaffen, Z., Rappenglück, M. A., Ernstson, K. Chrudim - Pardubice: Evidence for a Young Meteorite Impact Strewn Field in the Czech Republic // Lunar and Planetary Science Conference XLVIII. 2017. 1920. 
4. Shumilova, T. G., Isaenko, S. I., Ulyashev, V. V., Makeev, B. A., Rappenglück, M. A., Veligzhanin, A. A., Ernstson, K. Enigmatic Glass-Like Carbon from the Alpine Foreland, Southeast Germany: A Natural Carbonization Process// Acta Geologica Sinica. 2018. V. 92, P. 2179-2200.

5. Shumilova, T. G., Isaenko, S. I., Ulyashev, V. V., Kazakov, V. A., and Makeev, B. A. After-coal diamonds: an enigmatic type of impact diamonds // Eur. J. Min. 2018. V. 30. P. $61-76$.

6. Shumilova, T. G., Ulyashev, V. V., Kazakov, V. A., Isaenko, S. I., Vasil`ev, E. A., Svetov, S. A., Chazhengina, Y., Kovalchuk, N. S. Karite - diamond fossil: a new type of natural diamond // Geoscience Frontiers, 2019. https:// doi.org/10.1016/j.gsf.2019.09.011 